\title{
ADMINISTRATIVE LIABILITY \\ OF LEGAL ENTITIES AS LEGAL CATEGORY
}

\author{
Shevchuk O. M., Martynovskyi V. V.
}

\section{INTRODUCTION}

The issues of legal regulation of administrative responsibility of legal entities have always been relevant for legal science and practice. So, during 2014, the participants of the Antimonopoly Committee of Ukraine conducted 217 field inspections of legal entities to comply with the requirements of the legislation on the protection of economic competition. Based on the results of these inspections, consideration was started of 196 cases of violation of the law on the protection of economic competition and 159 recommendations were given on termination of actions (inaction) containing signs of offenses. As a result of the measures taken by the Committee, a total of 5341 violations of the law on the protection of economic competition were stopped, of which 2416 (45.2\%) were stopped by making decisions on the application of liability provided by law ${ }^{1}$. As can be seen from the above statistics, $45.2 \%$ of offenders were prosecuted for violation of the law on the protection of economic competition, fines were imposed on them in a total amount of more than $99300000 \mathrm{UAH}$.

In modern conditions, the activities of the state in the field of responsibility of legal entities have led to the fact that in different branches of law, scientists separately distinguish such types of responsibility of legal entities as financial, economic, economic, etc. ${ }^{2}$. In this case, the main attention is paid to such signs as, for example, the method of charging fines, the nature of the sanctions imposed on the ffender, and more ${ }^{3}$. On the other hand, it should be noted the lack of systematization of the administrative responsibility of legal entities by the legislator.

The legislation on the administrative responsibility of legal entities in Ukraine does not constitute a coherent system, it is dispersed and unsystematic. The Institute of Administrative Responsibility of Legal Entities in modern conditions contains many gaps and debatable issues, but there is no reason to deny its existence.

\footnotetext{
1 Звіт Антимонопольного комітету України за 2014 рік. URL. http://www.amc.gov.ua

2 Кондрашина Н.М. Окремі питання адміністративної відповідальності юридичних осіб. Науковий вісник Ужгор. наи. ун-ту. 2015. Вип. 32. Т. 3. С. 37. URL. https://dspace.uzhnu.edu.ua/

Бородін І.Л. Адміністративна відповідальність як різновид юридичної. Науковий вісник Львівського держ. ун-ту внутр. справ. Львів, 2006. С. 146. (Юрид. : Вип. 1)
} 
The relevance and significance of these problems, the need to solve them led to the choice of research topic.

\section{Genesis of the legislation of Ukraine on the administrative responsibility of legal entities}

The beginning of the formation and development of legislation on the administrative responsibility of legal entities in the scientific literature begins in 1917. Its active development is associated with the emergence of the New Economic Policy (NEP), as a result of which private entrepreneurial activity appears. After the end of the NEP period in the legislation, the administrative responsibility of legal entities remained. So, in the years 1930-1950, both individuals and legal entities were recognized as subjects of administrative responsibility. At that time, there was the responsibility of socialist organizations ${ }^{4}$.

In 1961, the Legislator recognized the existence of administrative liability of legal entities by canceling it. So, by the Decree of the Presidium of the Supreme Soviet of the USSR of June 21, 1961 (Ukraine - by the Decree of December 15, 1961 of the same name) "On further limiting the application of fines imposed in an administrative order", the application of fines to organizations, institutions and organizations in an administrative order was abolished. The purpose of this innovation of the legislator was to increase the personal responsibility of officials. This event became the basis for the fact that the subject of administrative responsibility could be exclusively an individual. This approach of exempting legal entities from administrative responsibility was applied in the decision of the Constitutional Court of Ukraine regarding the official interpretation of the provisions of paragraph 22 of part 1 of article 92 of the Constitution of Ukraine, parts 1 and 3 of article 2, part 1 of article 38 of the Code of Ukraine on Administrative Offenses ${ }^{5}$.

In the future, the development of legislation on the administrative responsibility of legal entities should be associated with the adoption in 1980 of the Fundamentals of the legislation of the USSR and union republics, and then in 1984-1985. So, by the introduction of the above Fundamentals of legislation, it was found that the entry into force of these

\footnotetext{
4 Жильцов О.Л. Адміністративна відповідальність юридичних осіб: процесуально-правовий аспект : автореф. дис. ... канд. юрид. наук. Харків, 2007. С. 6.

5 Рішення Конституційного Суду України щодо офіційного тлумачення положень пункту 22 частини першої ст. 92 Конституції України, частин першої, третьої ст. 2, част. 1 ст. 38 КУпАП (справа про відповідальність юридичних осіб). Офіційний вісник Украӥни. 2001. № 24. Ст. 1076.
} 
fundamentals does not affect existing legislative acts on the liability of legal entities in an administrative procedure. In 1984, the administrative liability of legal entities (including foreign organizations) was provided for committing offenses under the decree within the economic zone with a fine and confiscation of the offense (Decree of the Presidium of the Supreme Council of the USSR "On the Economic Zone of the USSR" dated 02.28.1984). After Ukraine was declared an independent democratic state, Ukraine continued to use the norms of the Ukrainian SSR Code of Administrative Offenses, which was adopted back in 1984. In this Code, only an individual was recognized as the subject of administrative responsibility, that is, the position of the legislator remained unchanged throughout the duration of the Code of Ukraine on administrative offenses ${ }^{6}$.

However, the institution of administrative liability of legal entities existed in other legislative acts and their appearance indicates that the development of this institution of liability occurs outside the provisions of the Code of Ukraine on administrative offenses. And in fact, a new period of development of legislation on the administrative responsibility of legal entities began to take shape. Its peculiarity is the restoration of the institute of administrative responsibility of legal entities, which began in the early 1990 upon the adoption of the Law of Ukraine of August 3, 1990 "On the economic independence of the Ukrainian SSR" ".

This period of development of this institution of responsibility is associated with changes in the economic system of society, in the methods and forms of government, as well as due to the processes of formation and development of entrepreneurship, the growth of a market economy, which led to the formation of a large number of legal entities based on private ownership. During the development of Ukraine's independence, the Verkhovna Rada of Ukraine adopted a number of laws of Ukraine that contain provisions on the administrative responsibility of legal entities.

An important step was also the adoption of the Commercial Code of Ukraine, in chapter 28 which addresses issues related to the administrative responsibility of legal entities. This chapter establishes a list of administrative penalties, which the legislator calls "administrative sanctions", provides a description of each of them, determines the terms for applying and guaranteeing the rights of legal entities in

\footnotetext{
6 Кондрашина Н.М. Окремі питання адміністративної відповідальності юридичних осіб. Науковий вісник Уэсгород. наи. ун.-ту. 2015. Вип. 32. Т. 3. С. 38. URL: https://dspace.uzhnu. edu.ua/

7 Про економічну самостійність Української PCP : Закон України від 3.07.1990p. URL: https://zakon.rada.gov.ua/
} 
the event of unlawful prosecution. The legislator officially recognized the administrative responsibility of legal entities in the Commercial Code of Ukraine, however, these provisions do not apply to all areas, but only to the sphere of monopolism restriction, protection of competition, protection of consumer rights, foreign economic activity, urban planning, advertising, execution of government orders, etc. ${ }^{8}$.

Also, the provision on the administrative responsibility of legal entities is contained in the Laws of Ukraine "On Employment", "On the Protection of Consumer Rights", "On the Association of Citizens", "On Public Associations", "On the Responsibility for Offenses in the Sphere of Urban Planning", "On the Exclusive (maritime) economic zone", "On state regulation of the securities market in Ukraine", "On public procurements" "On privatization of state property and communal property", in the Air Code of Ukraine, Tax Code of Ukraine, the Customs Code of Ukraine and some others.

In 2015, the Code of Ukraine on Administrative Offenses supplemented Article 14-2, which determines that administrative responsibility for offenses in the field of road safety, recorded automatically (using technical means to take pictures or videos, and operate in accordance with the law on the protection of information in information and telecommunication systems), are the legal entities and individuals on whom the vehicle is registered about. By this fact, the legislator at the level of the Code of Ukraine on Administrative Offenses recognized the administrative liability of legal entities.

In the current period of development of legislation on the administrative responsibility of legal entities, by analyzing legislative acts, the following options for administrative responsibility of legal entities can be distinguished.

The first is when the measures and the form of liability of a legal entity are defined directly in the legislative act. Such acts define the subject of responsibility - a legal entity and unlawful acts, the commission of which provides for liability in the form of financial (penal) sanctions 9 . An example would be: the Tax Code of Ukraine (Articles 111.1, 112, 113, 113.1-116.2 ${ }^{10}$; The Air Code of Ukraine (Article 127) ${ }^{11}$, Law of Ukraine

8 Господарський кодекс України : Закон України від 16.01.2003 р.№ 436-IV. Вiдомості Верховної Ради Украӥни. 2003, № 18, № 19-20, № 21-22. Ст. 144.

9 Демський Е.Ф., Добрянська Н.Л. Адміністративна відповідальність юридичних осіб. Вісник прокуратури: загальнодержавне фахове видання. 2012. № 3 (129). С. 106.

10 Податковий кодекс України : Закон України від 02.12.2010. Відомості Верховної Ради Украӥни. 2011. № 13-14, № 15-16, № 17. Ст. 112.

11 Повітряний кодекс України : Закон України від 19.05.2011 р. № 3393-VI. Вiдомості Верховної Ради Украӥни. 2011. № 48-49. Ст. 536. 
of October 30, 1996 № 448/96-BP “On State regulation of the securities market in Ukraine" (Article 11) ${ }^{12}$ and others.

The second one is when in a legislative act it is necessary to recognize as a liability subject not only a legal entity, but also an individual. The provisions of these laws do not establish either types of responsibility or specific entities, but they are called in a general form.

So, the Law of Ukraine dated 12.05.1991 "On the Protection of Consumer Rights" $" 13$ determines that in case of violation of the legislation on consumer protection, "business entities in the field of trade and other types of services, including restaurant industry, are responsible for ... "(Art. 23), - and further illegal acts are indicated, for which liability arises in the form of a fine. In this case, the subjects of responsibility can be both legal entities (enterprises, institutions, organizations), and individuals - entrepreneurs providing commercial, household and other services.

So, in Art. 1 of the Law of Ukraine "On liability for offenses in the field of urban development" established that offenses in the field of urban development are illegal acts (actions or inaction) of urban planning entities legal entities and individuals - entrepreneurs, which led to failure to comply or improper fulfillment of the requirements established legislation, building codes, government standards and regulations. Consequently, the subjects of urban planning are liable in the form of a fine for the implementation of preparatory work without notice of the beginning of their implementation, as well as for providing false data in such a message - in the amount of ten living wages for able-bodied persons ${ }^{14}$.

The third option is when the purpose of the legislative act on administrative liability of legal entities is to solve the specifics of applying financial sanctions (fines) and administrative responsibility. An example is the Law of Ukraine of February 18, 2018 № 2269-VIII “On the privatization of state property and communal property", part 2 of article 29 of which establishes that officials of privatization bodies and other executive bodies bear administrative responsibility, and according to part 3 of article 29 - officials of enterprises on whose balance sheets privatization objects are held administratively liable in the form of a fine Part 5 of this article provides for the responsibility of buyers (which

12 Про державне регулювання ринку цінних паперів в Україні : Закон України від 30.10.1996 p. № 448/96-ВР. Відомості Верховної Ради України. 1996. № 51. Ст. 252.

13 Про захист прав споживачів : Закон України від 12.05.1991 р. Відомості Верховної Ради України. 1991. № 30. Ст. 379.

14 Про відповідальність за правопорушення у сфері містобудівної діяльності : Закон України від 14.10.1994 р. Відомості Верховної Ради України. 1994. № 46. Ст. 411. 
aw person) in the case of sale of full or partial failure of contract terms. Such liability is established, for example, in the case of non-compliance by the buyer with obligations to preserve for a certain period the main activities of the privatized object, and therefore the buyer must pay a fine of 10 percent of the value of the acquired property ${ }^{15}$.

Thus, the genesis of the legislation of administrative responsibility in Ukraine in the twentieth century in the legal literature is conditionally divided into the following stages: 1) The emergence and formation during the New Economic Policy (1920), when there was almost no clear boundary between the responsibility of individuals and legal entities. Often this concerned private individuals (physical and legal). 2) A clear boundary between the administrative responsibility of individuals and legal entities was drawn in 1961 by the Decree of the Presidium of the Supreme Soviet of the USSR "On the further restriction of the use of fines imposed in an administrative procedure". 3) With the adoption in 1980 of the Fundamentals of the Legislation of the USSR and Union Republics, and then in 1984-1985 - codes of administrative offenses in the republics, the emphasis shifted to the responsibility of individuals. 4) 1990 - the modern stage, the essence of which is to restore the administrative responsibility of legal entities. The features of this stage are associated with the transition to market relations, the proclamation of equality of the legal status of all forms of ownership, the adoption of a number of laws that establish the administrative responsibility of legal entities ${ }^{16}$.

However, from our point of view, the "modern stage" should be limited to 2015. It should also highlight the stage of development of legislation from 2015 to the present, taking as a criterion the inclusion of administrative liability of legal entities in the Code of Ukraine on Administrative Offenses. The Law of Ukraine "On Amending Certain Legislative Acts of Ukraine Regarding Improving Regulation of Relations in the Sphere of Ensuring Road Safety" of July 14, 2015 amended the Code of Ukraine on Administrative Offenses. Until July 14, 2015 , the development of the institution of administrative liability of legal entities took place outside the Code of Ukraine on Administrative Offenses. According to the current Code of Ukraine on administrative

15 Про приватизацію державного майна та комунального майна: Закон України від 18.02.2018 р. № 2269-VIII. Голос Украӥни. 2018. № 44.

16 Кондрашина Н.М. Окремі питання адміністративної відповідальності юридичних осіб. Науковий вісник Ужгород. наи. ун-ту. 2015. Вип. 32. Т. 3. С. 37. URL: https://dspace.uzhnu.edu.ua/ 
offenses, the subjects of administrative responsibility are individuals (Article 13), officials (Article 14) and legal entities (Article 142) ${ }^{17}$.

Recall that according to paragraph 1 of Article 142 of the Code of Ukraine on Administrative Offenses, administrative responsibility for offenses in the field of road safety is recorded automatically (using technical means that allow you to take pictures or videos and operate in accordance with the legislation on the protection of information in information and telecommunication systems) are carried by legal entities and individuals in whose name the vehicle is registered. In turn, paragraph 4 of Article $142^{2}$ establishes that the legal entity for which the vehicle is registered or which imported the vehicle into the territory of Ukraine is exempt from liability for administrative offenses in the field of road safety, recorded automatically, if the vehicle his license plate was dropped from the ownership of the owner as a result of unlawful actions of other persons.

So, at the legislative level, administrative liability is established for legal entities. In addition, article 80 of the Civil Code of Ukraine determines that a legal entity is an organization created and registered in accordance with the law. A legal entity is endowed with civil legal capacity and legal capacity, may be a plaintiff and defendant in court ${ }^{18}$.

\section{Administrative liability of legal entities as an independent type of administrative responsibility}

Administrative responsibility is one of the basic concepts of administrative law. However, there is no consensus among scientists regarding the classification of legal entities as subjects of administrative responsibility. So, S. I. Saenko claims that a legal entity as a subject of administrative legal relations is a collective subject of law, which, on the basis of its legal personality in specific administrative legal relations, exercises its subjective legal rights and fulfills duties, and is also responsible for committed administrative offenses ${ }^{19}$.

P. Lyutikov believes that all legal entities founded by the state have the attribute of public entities, and the legal form (joint-stock companies, etc.) cannot serve as the basis for considering such individuals as private ${ }^{20}$.

17 Кодекс України про адміністративні правопорушення : Закон України від 07.12.1984 р. № 8073-Х. Відомості Верховної Ради Украӥнської РСР. 1984, додаток до № 51. ст. 1122.

18 Цивільний кодекс України : Закон України від 16.03.2003 p. № 435-IV. Офіиійний вісник України. 2003. № 11. Ст. 461.

19 Саєнко С.I. Адміністративна відповідальність юридичних осіб за правопорушення в сфері обігу наркотичних засобів : дис. ... канд. юрид. наук : 12.00.07. Харків, 2007. С. 13.

20 Лютіков П.С. Адміністративно-правовий статус юридичних осіб: аналіз структури та поняття. Європейські перспективи. 2013. № 2. С. 19-25. 
According to I. Gavrilova, public legal entities endowed with authority can not be subject to administrative responsibility, since public authorities, local authorities will bear administrative responsibility for a responsible official only subjectively ${ }^{21}$.

A. Zima motivates the need for the existence of administrative responsibility of legal entities by the fact that the latter are not only participants in public and legal relations. They also act as one of the objects of government. Thus, the bodies of state executive power, exercising public administration, must make a certain impact on them, apply the appropriate managerial (regulatory) methods. According to one of the common classifications, these methods are divided by conviction and coercion, one of which is administrative responsibility ${ }^{22}$.

V. Krotyuk, A. Ioffe, D. Lukyanets believe that legal entities are not the subjects of administrative offenses in the context of the Code of Administrative Offenses, but administrative relations in a broad sense also cover relations involving legal entities ${ }^{23}$. A. Zima defines a system of features that distinguish the administrative responsibility of a legal entity from the administrative responsibility of an individual. In particular, they stand out: a specific (not special) subject of responsibility; legal behavior of the subject, which is implemented in the activities of individuals constituting the social substrate of a legal entity, as a result of which the guilt of a legal entity is seriously different from the guilt of a physical person; the penalty applied to the offender, which entails negative consequences not only in relation to the offender (legal entity), but also to individuals associated with it ${ }^{24}$. L. Kravchenko and A. Pletneva argue that in the conditions of the development of market relations and the emergence of a large number of business entities of various organizational and legal forms, the norms of the current Code of Ukraine on administrative offenses apply not only to individuals, but also to legal entities ${ }^{25}$. However, in the opinion of M.V. Udod, A.G. Litus, in modern conditions, enough regulatory acts

${ }^{21}$ Гаврилова І.О. Юридичні особи як суб'єкти адміністративної відповідальності. Юридичний вісник «Повітряне та космічне право». 2016. № 2 (39). С. 71.

22 Зима О.А. Адміністративна відповідальність юридичних осіб : автореф. дис. ... канд. юрид. наук : 12.00.07. Харків, 2001. С. 10.

23 Кротюк В., Іоффе, А., Лук'янець Д. Фінансові санкції та адміністративна відповідальність: проблема співвідношення. Право України. 2000. № 5. С. 31.

24 Зима О.А. Адміністративна відповідальність юридичних осіб : автореф. дис. ... канд. юрид. наук. Харків, 2001. С. 11.

25 Кравченко Л., Плетньова О. Проблеми адміністративної відповідальності юридичних осіб у сфері валютного законодавства. Юридичний журнал. 2004. № 8. С. 69. 
have already been adopted that allow administrative measures to be applied to legal entities ${ }^{26}$.

Based on the foregoing, it can be concluded that legal entities are the dominant participants in administrative law, as they are manifested in government bodies, local governments, public law unions that can acquire the status of legal entities, as well as in various business societies, unions, institutions or corporations voluntarily created by private individuals, etc., and emphasize the need for recognition of legal entities as subjects of administrative responsibility.

You should pay attention to the legislation of foreign countries on the administrative responsibility of legal entities. Thus, in the legislation on offenses of the Portuguese Republic, namely, in article 7 of Law Decree № 433/82 of 10/27/1982, collective or similar persons are liable for misconduct ${ }^{27}$. Law of the Republic of Slovenia "On Misconduct" № 163 of December 12, 2002 provides for liability of a legal entity, its responsible person and independent private entrepreneur and entrepreneur, which independently carries out activities. This normative act stipulates that the Republic of Slovenia and local authorities are not responsible for misconduct. The law determines that the offense is the responsibility of the responsible person of the state body or local government ${ }^{28}$. The Law of the Republic of Serbia "On Misconduct" stipulates that the subjective composition of the persons responsible for misconduct is clearly provided for in Article 17 "Subjects and Conditions of Responsibility for Misconduct", which provides for the specification of the conditions of responsibility ${ }^{29}$.

Thus, the administrative responsibility of legal entities should be considered as an independent type of administrative responsibility. The administrative responsibility of legal entities is carried out on the general principles of administrative responsibility, has the characteristics inherent in the administrative responsibility of individuals, that is, it is established by laws and other normative acts, the norms of which form an independent institution of administrative law.

26 Удод М.В., Літус О.Г. Адміністративна відповідальність юридичних осіб. Вісник Академії митної служби Украӥни. Серія: Право : науковий журнал. 2010. № 1. С. 90-91.

27 Декрет-Закон Португальської Республіки, від 27.10.1982 p. URL. http://pravo.org.ua/ files/zarub_zakon/Port_1982.pdf

28 Про проступки : Закон Республіки Словенія від 12.12.2002 p. URL.http://pravo.org.ua/ files/zarub_zakon/Slov_2002.pdf

29 Про проступки : Закон Республіки Сербія від 01.01.2007 p. URL: http://pravo.org.ua/ files/zarub_zakon/Serb_2007.pdf 


\section{Wines of legal entities, the purpose and grounds of administrative liability of legal entities}

The issue of the guilt of a legal entity as a subject of administrative responsibility among scientists remains in the process of study. The problem of bringing legal entities to administrative responsibility lies, in particular, in proving guilt. Legal entities, like individuals, are full-fledged subjects of many types of legal relations, and therefore can commit various illegal acts. The guilt of legal entities, of course, has its own special nature and acts as a complex socio-psychological phenomenon, as the fault of the whole team, and not just its individual employee ${ }^{30}$.

Establishing guilt as an element of an administrative offense allows us to distinguish between cases in which a legal entity's failure to fulfill its obligations was a consequence of circumstances beyond its control, and it was not subject to prosecution, as well as cases in which a person guilty of an offense, must be held accountable.

Today, among administrative scientists, there is no consensus on guilt as a sign of the subjective side, since a significant number of legal scholars generally object to the mandatory presence of the subjective side as part of an administrative offense committed by a legal entity. The main reason for this, they see the lack of mind and mental attitude to the acts committed by them ${ }^{31}$, which, in turn, makes it impossible to apply to the legal entity a classical approach to understanding the concept of "guilt".

A legal entity has its own subjective interest and will. It is worth noting that there are various concepts for determining the guilt of a legal entity. The guilt of a legal entity cannot be identified with the guilt of a particular employee, as well as with the guilt of the bodies of a legal entity, moreover, the guilt of an employee is a necessary condition for the guilt of a legal entity, the guilt of a legal entity may be a consequence of the guilt of the employee ${ }^{32}$.

In modern conditions of development of the institute of administrative responsibility of legal entities, two scientific approaches to understanding the guilt of a legal entity are used. The first (psychological) - are the views of scientists who understand guilt as "the mental attitude of a person to his illegal behavior". Such an understanding of guilt can be applied to both individuals and legal entities (M.M. Agarkov, A.S. Ioffe, I.S. Kanzafarova,

\footnotetext{
30 Матвеев Г.К. Основания гражданско-правовой ответственности. Москва : Юрлитиздат, 1970. C. 210.

31 Бахрах Д.Н. Субъекты советского административного права. Свердловск, 1985. С. 99.

32 Гражданское право Украины : учебник. Ч. 1 / Под ред. А.А. Пушкина и В.М. Самойленко. Харьков : Основа, 1996. С. 230.
} 
G.K. Matveev, V.A. and others). The above approach received a number of criticisms, since it is at least incorrect to talk about the "mental attitude" of a legal entity. However, according to the supporters of the psychological approach, the activity of a legal entity is expressed in one way or another through the actions of people (decisions of bodies, transactions of representatives, actions of participants and employees), whose mental attitude to committing (imperfection) of legally significant actions should be recognized as the content of the guilt of the legal entity ${ }^{33}$.

The second approach to understanding the guilt of a legal entity is "behavioral theory" (M.I. Braginsky, V.V. Vitryanskiy, E.A. Sukhanov, N.V. Kozlova, N.N. Khomenko and others), according to which for guilty determination uses an abstract model of expected behavior in a specific situation of a reasonable and bona fide participant in the property turnover. Such an understanding of guilt is based on the wording of the fact that a person is recognized not guilty if, with the degree of care and discretion that was required of her by the nature of the obligation and the terms of the turnover, she took all measures to properly fulfill the obligation. This approach gives reason to say that the categories that determine guilt and its forms are reasonableness and discretion. Moreover, a certain degree of them is taken into account, which must correspond to the nature of a specific obligation, the conditions for the circulation of goods at which the fulfillment of such an obligation takes place, and also measures that were taken for the proper fulfillment of the obligation are taken into account ${ }^{34}$.

Considering the foregoing, we can conclude: the concept of "guilt" characterizes the conscious, mental attitude of a person to the wrongful act committed by him and its consequences. In the scientific literature on these issues, it was noted that the guilt of a legal entity cannot be arbitrarily determined only if the guilt of a particular official is revealed. Proof of the guilt of all employees acting on behalf of the organization as a whole. However, in the science of administrative law, there is also another approach to the concept of guilt of a legal entity, when the guilt of a legal entity is defined as a set of negative elements characterized by disorganization of the activities of a legal entity, failure to take the necessary measures for the proper performance of its duties, lack of necessary efforts to prevent offenses and eliminate their causes.

\footnotetext{
33 Жорнокуй В. Вина юридичної особи: сучасний стан учення. Підприємство, господарство і право. 2020. № 1. C. 161. DOI https://doi.org/10.32849/2663-5313/2020.1.29

34 Гражданское право: актуальные проблемы теории и практики / под общ. ред. В.А. Белова. Москва : Юрайт-Издат, 2008. С. 296-297.
} 
It is advisable to be guided by the definition of guilt ofalegal entity proposed by A.T. Zima. According to him, the guilt of a legal entity is a subjective attitude towards the misconduct of individuals who are part of the legal entity or are in another relationship with it (membership, ownership), and whose labor or managerial powers are connected with the commission of an unlawful act. Guilt should be determined by the prevailing will, which should be understood as the will of the administration, other persons who are given the right to give instructions within the legal entity and its units. That is, a legal entity is considered guilty if it has committed unlawful actions that are the result of actions (inaction) of individuals that are part of a legal entity, the consequences of these actions were recognized or should have been recognized by these individuals ${ }^{35}$.

Viktorov I. believes that the establishment of the guilt of a legal entity may directly depend on the guilt of the official or may be caused by the guilt of the official, whose actions led to the commission of the unlawful act for which the legal entity is responsible ${ }^{36}$. A.T. Zima highlights the general and special subjects of misconduct. The general subject of the offense is a legal entity, that is, one that has passed the state registration procedure in the manner established for this type of legal entity and included in the Unified State Register. There is also a special subject - a legal entity, which, in addition to general ones, has special, additional features. Such signs necessary for the status of a special subject can be acquired in two ways: (1) regulatory (obtaining state permission, license, delegation of authority, the presence of which makes it possible to commit an offense); (2) actual (acquisition of certain real features (monopoly position in the market) that are not related to state permission, but in the absence of which a specific offense cannot be committed ${ }^{37}$.

So, most scholars believe that the guilt of a legal entity is always the fault of people and can not be anything else, and they try to uncover the concept of guilt of a legal entity from the standpoint of establishing its "human substrate", whether it be the head, administration, individual officials or ordinary employees, labor collective as a whole. The transformation of the legal entity into one of the main participants in the property turnover also contributed to the depreciation of the criterion of guilt as a necessary

35 Зима О.Т. Адміністративна відповідальність юридичних осіб : автореф. дис. ... канд. юрид. наук. Харків, 2001. С. 11-12.

36 Викторов И. Административная ответственность юридических лиц. Законность. 2001. № 6. С. 12-13.

37 Зима О.Т. Адміністративна відповідальність юридичних осіб : автореф. дис. ... канд. юрид. наук. Харків, 2001. С. 12. 
condition for civil liability. Note that the guilt of a legal entity as a subject of civil liability may manifest itself in the form of: 1) the fault of its bodies (part 1 of article 92 of the Civil Code of Ukraine); 2) the fault of its participants (part 2 of article 92 of the Civil Code of Ukraine); 3) the fault of its employees or officials who are not bodies of a legal entity and perform their labor functions (Article 1172 of the Civil Code of Ukraine) ${ }^{38}$.

Recently, the issue of expanding the liability of participants in legal entities (especially business companies) has been actively discussed by imposing additional (subsidiary) liability on them and, as a result, causing the legal entity itself and its creditors losses due to the adoption of erroneous decisions in advance (or majority by the participant during the general meeting, or by officials of the executive body or the supervisory board, who are mainly appointed by the majority nickname) $)^{39}$.

Examples of the above circumstances are consolidation in part 6 of Art. 126 of the Commercial Code of Ukraine (subsidiary liability of a holding company for the obligations of a corporate enterprise) ${ }^{40}$ and Art. 58 of the Law of Ukraine "On Banks and Banking"41 (liability of a person associated with a bank for violating the requirements of the law on risky operations that threaten the interests of depositors or other creditors of the bank, or making the bank insolvent). According to the level of assessment of the guilt of legal entities and the characteristics of the objective side, several types of administrative offenses of legal entities can be distinguished: an objectively guilty act, a complex offense, an offense with a separate subject.

In the first case: in Art. 22-26 of the Law of Ukraine "On the exclusive (marine) economic zone of Ukraine" established the liability of legal entities for:

1) illegal exploration or development of natural resources of the exclusive (marine) economic zone of Ukraine, as well as the creation of artificial islands, the construction of installations and structures, the establishment of security zones around them without the permission of a specially authorized body of Ukraine;

\footnotetext{
38 Жорнокуй В. Вина юридичної особи: сучасний стан учення. Підприємство, господарство і право. 2020. № 1. C. 163. DOI https://doi.org/10.32849/2663-5313/2020.1.29

39 Спасибо-Фатєєва І.В. Про концептуальні зміни в підходах до відповідальності акціонерів та посадових осіб господарських товариств. Право і суспільство. 2016. Вип. 3. С. 126.

40 Господарський кодекс України : Закон України від 16.01.2003 р. № 436-IV. Biдомості Верховної Ради Украӥни. 2003. № 18, № 19-20, № 21-22. Ст. 144.

41 Про банки та банківську діяльність : Закон України від 07.12.2000 р. № 2121-II. URL: https://zakon.rada.gov.ua/laws/show/2121-14
} 
2) non-provision of installations or other structures located in the exclusive (marine) economic zone of Ukraine, permanent means of warning of their availability, violation of the rules for maintaining these funds in proper condition or violation of the rules for the liquidation of those structures whose operation has been permanently discontinued;

3) illegal extraction of natural resources within the exclusive (marine) economic zone of Ukraine;

4) illegal conduct of marine scientific research in the exclusive (marine) economic zone of Ukraine ${ }^{42}$. That is, these violations can be solely the result of active conscious actions by individuals included in the legal entity.

An objectively guilty act as the basis of the administrative liability of legal entities takes place if the unlawful act consists in active actions that violate the prohibitions established by law. Many laws of Ukraine provide for the administrative liability of legal entities for acts that cannot but result from actions or inaction of individuals that are part of a legal entity.

In the second case: the objective side of the offenses under Art. 46 of the Law of Ukraine "On ensuring the sanitary and epidemiological wellbeing of the population" 43 coincides with the objective side of the offense under Art. 42 of the Code of Ukraine on Administrative Offenses.

Thus, the determination of the unlawfulness of the actions of a legal entity in full takes place in those cases when the participants in the relations of administrative responsibility are both the legal and physical persons that are its members. In particular, this applies to cases when, for one administrative offense, the legal entity itself and its official are simultaneously held administratively liable. The subjects of such offenses are, as a rule, officials of enterprises, institutions and organizations, and the objective side of these unlawful acts for officials has two components: the actions of an individual official and the actions of the legal entity itself. Moreover, the actions of a legal entity is a consequence of unlawful actions of the relevant officials. At the same time, the objective side of the corresponding offenses of legal entities, the responsibility for the commission of which is provided for by separate laws, also consists of the same actions, but only of a legal entity.

In the third case (in relation to offenses with a separate subject), the objective side of the offense is expressed in the unlawful actions of a legal entity, and its official is the subject of the offense. As an example,

42 Про виключну (морську) економічну зону України : Закон України. Відомості Верховної Ради Украӥни. 1995. № 21. Ст. 152.

43 Про забезпечення санітарного та епідеміологічного благополуччя населення : Закон України. Відомості Верховної Ради України. 1994. № 27. Ст. 218. 
Art. 170 of the Code of Ukraine on administrative offenses. For an official to be recognized as the subject of such an offense, there must be a connection between the actions of this official and the unlawful actions of a legal entity. The only option for such a connection can only be that the unlawful actions of a legal entity are a consequence of the actions of its official. In this case, we are talking about offenses with a separate subject. It occurs when the necessary sign of its objective side is the unlawful actions of a legal entity, and the subject is an official acting on his behalf, or one whose actions directly entailed the unlawful actions of a legal entity.

Therefore, it should be noted that the provisions set forth in many laws require further legislative regulation, namely, the specification of the grounds for administrative responsibility for the offenses committed, the definition of a system of penalties that can be applied to legal entities-offenders, the regulation of the procedure for imposing administrative penalties, appeal against actions government bodies and the like. At the same time, a number of legislative acts contain a detailed statement of issues relating to the administrative responsibility of legal entities.

\section{CONCLUSIONS}

Legal entities are subjects of an administrative offense, and measures of administrative responsibility may be applied to them. The administrative responsibility of legal entities is carried out on the general principles of administrative responsibility, has the characteristics inherent in the administrative responsibility of individuals, that is, it is established by laws and other normative acts, the norms of which form an independent institution of administrative law.

The administrative responsibility of legal entities has a social value, the purpose of which is to apply state coercion measures against offenders, prevent the commission of new offenses, ensure the protection and restoration of violated rights and interests, educate offenders in the spirit of compliance with the laws of Ukraine and respect for hostel rules. The administrative responsibility of legal entities is intended to counter offenses in relation to the established management procedure and state discipline. It must protect the legitimate rights and interests of citizens, the state, other legal entities, as well as the established management procedure.

In modern conditions in Ukraine, the codification of legislation on the development of the institution of administrative responsibility of legal entities will allow more efficient application of the relevant legal norms, as well as create a reliable basis for further work in the direction of optimizing 
legislation and the practice of its implementation. In addition, improving national legislation, it is necessary to take into account the experience of foreign countries (Slovenia, Serbia, Portugal), it is necessary to highlight a separate section in the Code of Ukraine on administrative offenses regarding the administrative liability of legal entities.

\section{SUMMARY}

The article is devoted to the analysis of the legal problems of the development and establishment of legislation on the institution of administrative responsibility of a legal entity both national and international, as well as scientific works on this issue. It is determined that the administrative responsibility of legal entities can be considered as an independent type of administrative responsibility. The scientific approaches to the development of the institute of administrative responsibility of legal entities are highlighted, its essence, content, features are characterized.

The historical stages of the development of legislation on the administrative responsibility of legal entities are established. It has been found that starting in 2015, the Code of Ukraine on Administrative Offenses defines the subjects of administrative responsibility as individuals (Article 13), officials (Article 14), and legal entities (Article 142). It was stated that in the case of an administrative offense by a legal entity, three possible legal consequences are possible: 1) holding the legal entity accountable, as in the case of a violation of the rules; 2) prosecution of both a legal entity and officials, as in the case of a violation in the field of restriction of monopoly; 3) holding only an official accountable as a violation of customs regulations.

The concept and content of guilt of legal entities, the purpose and grounds of administrative responsibility of legal entities are studied. It is proposed that according to the level of assessment of the guilt of legal entities and the features of the objective side, several types of administrative offenses of legal entities can be distinguished: 1) an objectively guilty act, 2) a complex offense, 3) an offense with a separate subject. It is proposed to carry out codification of legislation on the development of the institution of administrative liability of legal entities, which will allow more efficient application of the relevant legal norms and provide for a separate section on the administrative liability of legal entities in the Code of Ukraine on Administrative Offenses. 


\section{REFERENCES}

1. Звіт Антимонопольного комітету України за 2014 рік. URL: http:// www.amc.gov.ua/

2. Кондрашина Н.M. Окремі питання адміністративної відповідальності юридичних осіб. 2015. Вип. 32. Т. 3. С. 36-39. URL: https://dspace.uzhnu.edu.ua/

3. Бородін І.Л. Адміністративна відповідальність як різновид юридичної. Науковий вісник Львівського держ. ун-ту внутр. справ. 2006. C. $140-149$.

4. Жильцов О.Л. Адміністративна відповідальність юридичних осіб: процесуально-правовий аспект : автореф. дис. ... юрид. наук. Харків, 2007. 19 c.

5. Рішення Конституційного Суду України щодо офіційного тлумачення положень пункту 22 частини першої ст. 92 Конституції України, част. 1, 3 ст. 2, част. 1 ст. 38 КУпАП (справа про відповідальність юридичних осіб). Офіщійний вісник України. 2001. № 24. Ст. 1076.

6. Про економічну самостійність Української РСР : Закон України від 03.07.1990 p. URL: https://zakon.rada.gov.ua/

7. Господарський кодекс України : Закон України від 16.01.2003 р. № 436-IV. Відомості Верховної Ради України. 2003. № 18, № 19-20, № 21-22. Ст. 144.

8. Демський Е.Ф., Добрянська Н.Л. Адміністративна відповідальність юридичних осіб. Вісник прокуратури: загальнодержавне фахове видання. 2012. № 3 (129). С. 105-114.

9. Податковий кодекс України: Закон України від 02.12.2010 p. Відомості Верховної Ради України. 2011. № 13-14, № 15-16, № 17. Ст. 112.

10. Повітряний кодекс України: Закон України від 19.05.2011 p. № 3393-VI. Відомості Верховної Ради України. 2011. № 48-49. Ст. 536.

11. Про захист прав споживачів: Закон України від 12.05 .1991 р. Відомості Верховної Ради України. 1991. № 30. Ст. 379.

12. Про відповідальність за правопорушення у сфері містобудівної діяльності : Закон України від 14.10.1994 р. Відомості Верховної Ради України. 1994. № 46. Ст. 411.

13. Про державне регулювання ринку цінних паперів в Україні : Закон України від 30.10.1996 р. № 448/96-ВР. Відомості Верховної Ради України. 1996. № 51. Ст. 252.

14. Про приватизацію державного майна та комунального майна : Закон України від 18 лютого 2018 р. № 2269-VIII. Голос України. 2018. № 44.

15. Кодекс України про адміністративні правопорушення: Закон України від 07.12.1984 р. № 8073-Х. Відомості Верховної Ради Української РСР. 1984. Додаток до № 51. Ст. 1122 
16. Цивільний кодекс України: Закон України від 16.03.2003 р. № 435-IV. Офіиійний вісник Украӥни. 2003. № 11. Ст. 461.

17. Саєнко С.І. Адміністративна відповідальність юридичних осіб за правопорушення в сфері обігу наркотичних засобів : дис. ... канд. юрид. наук. Харків, 2007. 238 с.

18. Лютіков П.С. Адміністративно-правовий статус юридичних осіб: аналіз структури та поняття. Свропейські перспективи. 2013. № 2. С. 19-25.

19. Гаврилова I.О. Юридичні особи як суб'єкти адміністративної відповідальності. Юридичний вісник «Повітряне та космічне право». 2016. № 2 (39). С. 68-74.

20. Зима О.А. Адміністративна відповідальність юридичних осіб : автореф. дис...канд. юрид. наук. Харків, 2001. 19 с.

21. Кротюк В., Іоффе А., Лук'янець Д. Фінансові санкції та адміністративна відповідальність: проблема співвідношення. Право України. 2000. № 5. С. 29-33.

22. Удод М.В., Літус О.Г. Адміністративна відповідальність юридичних осіб. Вісник Академї̈ митної служби Украӥни. Серія: Право : науковий журнал. 2010. № 1. С. 90-95.

23. Кравченко Л., Плетньова О. Проблеми адміністративної відповідальності юридичних осіб у сфері валютного законодавства. Юридичний журнал. 2004. № 8. С. 69-72.

24. Декрет-Закон Португальської Республіки від 27.10.1982 p. URL: http://pravo.org.ua/files/zarub_zakon/Port_1982.pdf

25. Про проступки : Закон Республіки Словенія від 12.12.2002 p. URL: http://pravo.org.ua/files/zarub_zakon/Slov_2002.pdf

26. Про проступки : Закон Республіки Сербія від 01.01.2007 p. URL: http://pravo.org.ua/files/zarub_zakon/Serb_2007.pdf

27. Матвеев Г.К. Основания гражданско-правовой ответственностию. Москва : Юрлитиздат, 1970. 218 с.

28. Бахрах Д.Н. Субъекты советского административного права. Свердловск, 1985. 168 с.

29. Гражданское право Украины : учебник. Ч. 1 / Под ред. А.А. Пушкина и В.М. Самойленко. Харьков : Основа, 1996. 422 с.

30. Викторов И. Административная ответственность юридических лиц . Законность. 2001. № 6. С. 12-13.

31. Жорнокуй В. Вина юридичної особи: сучасний стан учення. Підприємство, господарство і право. 2020. 1. С. 160-164. DOI https://doi.org/10.32849/2663-5313/2020.1.29

32. Спасибо-Фатєєва I.В. Про концептуальні зміни в підходах до відповідальності акціонерів та посадових осіб господарських товариств. Право і суспільство. 2016. Вип. 3. С. 124-132. 
33. Про банки та банківську діяльність : Закон України від 07.12.2000 p. № 2121-II. URL: https://zakon.rada.gov.ua/laws/show/2121-14

34. Про виключну (морську) економічну зону України : Закон України від 16.05.1995 р. № 162/95-BP. URL: https://zakon.rada.gov.ua

35. Про забезпечення санітарного та епідеміологічного благополуччя населення : Закон України від 24.02.1994 р. № 4004-XII. Вiдомості Верховної Ради Украӥни. 1994. № 27. Ст. 218.

\section{Information about author:}

Shevchuk O. M.,

Doctor of Juridical Sciences,

Professor at the Department of Administrative Law and Administrative

Activities

Yaroslav Mudryi National Law University

77, Pushkinska str., Kharkiv, Ukraine

Martynovskyi V. V., Ph.D., Associate Professor at the Department of Administrative Law and Administrative Activities Yaroslav Mudryi National Law University 77, Pushkinska str., Kharkiv, Ukraine

DOI https://doi.org/10.30525/978-9934-588-43-3/2.28 